\title{
FAKTOR-FAKTOR YANG MEMENGARUHI PELAKSANAAN FUNGSI KELUARGA DI INDONESIA
}

\author{
Tin Herawati $^{\left.{ }^{*}\right)}$, Diah Krisnatuti ${ }^{1}$, Resti Pujihasvuty², Eka Wulida Latifah ${ }^{1}$ \\ ${ }^{1}$ Departemen IImu Keluarga dan Konsumen, Fakultas Ekologi Manusia, \\ IPB University, Bogor 16680, Indonesia \\ 2Badan Kependudukan dan Keluarga Berencana Nasional, Jakarta 13650, Indonesia
}

")E-mail: gmsk_29@yahoo.com

\begin{abstract}
Abstrak
Pelaksanaan fungsi keluarga yang optimal dapat mendukung terwujudnya sumber daya manusia dan keluarga yang berkualitas. Karakteristik keluarga dapat memengaruhi optimalisasi fungsi keluarga. Penelitian ini bertujuan untuk menganalisis pengaruh karakteristik sosial ekonomi, pengetahuan, dan akses informasi terhadap fungsi keluarga. Penelitian ini menggunakan desain cross sectional study dengan data sekunder dari Survei Indikator Kinerja Rencana Pembangunan Jangka Menengan Nasional tahun 2017. Pengolahan dan analisis data dilakukan secara deskriptif dan inferensial menggunakan tabulasi silang dan uji regresi. Hasil penelitian menunjukkan bahwa proporsi responden terbanyak berusia dewasa akhir dan pendidikan sekolah dasar. Fungsi agama, ekonomi dan lingkungan adalah fungsi yang paling banyak diketahui oleh responden, sedangkan proporsi responden terbanyak mengetahui mengenai kependudukan berada kategori tinggi. Temuan menariknya adalah keluarga yang tinggal di perdesaan memiliki fungsi keluarga yang lebih baik dibandingkan dengan yang tinggal di perkotaan. Faktor yang berpengaruh signifikan terhadap pelaksanaan fungsi keluarga adalah usia, status perkawinan, status pekerjaan, tingkat pendidikan, pengetahuan fungsi keluarga, dan akses informasi. Hasil penelitian ini merekomendasikan perlunya sosialisasi fungsi keluarga secara intens ke sasaran utama program yaitu keluarga yang tinggal di perkotaan, keluarga pasangan usia muda, dan keluarga dengan tingkat pendidikan rendah.
\end{abstract}

Kata kunci: akses informasi, fungsi keluarga, karakteristik keluarga, pengetahuan keluarga, sosial ekonomi keluarga

\section{Factors Affecting The Implementation of Family Functions in Indonesia}

\begin{abstract}
The optimal implementation of family functions can support the realization of the quality of human and family resources. Family characteristics can influence the optimization of family functions. This study aims to analyze the effect of socioeconomic characteristics, level of knowledge, and access to information on the implementation of family functions. This study used a cross-sectional study design with secondary data from the 2017 National MidTerm Development Plan Performance indicators Survey. Data processing and analysis were done descriptively and inferentially using cross-tabulation and regression tests. The results showed that the highest proportion of respondents were in late adulthood and primary school education. The function of religion, economic, and environment were the most widely known by respondents, while the proportion of respondents who know the most about the population was in the high category. An interesting finding is that Families who live in rural areas have better family functions than families who live in urban areas. Factors that significantly influence the implementation of family functions are age, marital status, employment status, educational level, knowledge of family functions, and access to information. The results of this study recommend intense socialization of family functions to the main targets of the program, namely families living in urban areas, families of young couples, and families with low levels of education.
\end{abstract}

Keywords: access to information, family characteristics, family functions, family knowledge, family socio economic

\section{PENDAHULUAN}

Tantangan yang dihadapi Bangsa Indonesia dalam jangka menengah dan panjang, salah satunya adalah mempersiapkan kualitas sumber daya manusia untuk menyongsong
Indonesia Sejahtera Tahun 2025 dan Generasi Emas Tahun 2045. Kunci sukses dalam mempersiapkan Sumber Daya Manusia (SDM) Indonesia yang berkualitas harus dimulai sejak dini dari tingkat keluarga. Deacon dan Firebaugh (1988) menyatakan bahwa sebagai 
penghasil SDM, keluarga harus menjalankan fungsinya dengan baik agar dapat menghasilkan sumber daya manusia yang berkualitas. Salah satu kebijakan yang mendukung pembangunan keluarga berkualitas adalah dengan memberdayakan penerapan fungsi-fungsi keluarga secara optimal sehingga kualitas anak, remaja, dan lansia meningkat (BKKBN, 2018).

Ketahanan dan kesejahteraan keluarga dapat terwujud apabila keluarga dapat mengoptimalkan pelaksanaan fungsi keluarga. Pelaksanaan dan Pemenuhan fungsi keluarga yang optimal sangat penting bagi setiap keluarga (Sunarti, 2013). Keluarga yang sejahtera memiliki fungsi yang optimal sehingga keluarga tersebut dapat mengakomodasi adanya kebutuhan dasar dan coping anggotanya, serta mampu melakukan penyesuaian terhadap tuntutan diri dan lingkungan (Dewi dan Ginanjar, 2019). Kunci sukses pelaksanaan fungsi keluarga ada di tangan orang tua sebagai pengendali keluarga. Fahrudin (2012) menyatakan bahwa orang tua memiliki peran paling penting dalam keberfungsian keluarga. Nilai-nilai yang terdapat dalam fungsi keluarga dapat diajarkan dan ditanamkan orang tua kepada anak dalam kehidupan sehari hari. Fungsi keluarga yang mampu dijalankan dengan baik oleh orang tua dapat memengaruhi anggota keluarga lain terutama anak. Hal ini sesuai dengan beberapa penelitian yang mengatakan bahwa fungsi keluarga berpengaruh terhadap perilaku anak (Priasmoro, Widjajanto, \& Supriari, 2016) dan remaja (Freed, Rubenstein, Daryanani, Olino, \& Alloy, 2016; Henneberger, Durkee, Truong, Atkins, \& Tolan, 2016; Maulina \& Amalia, 2019). Selain itu, Richardson dan Gleeson (2018) juga menyatakan bahwa perbaikan fungsi keluarga berpengaruh positif terhadap kualitas dan kesejahteraan anak. Kondisi tersebut disebabkan karena fungsi keluarga memengaruhi gaya pengasuhan orang tua terhadap anak.

Menurut teori sistem (Puspitawati, 2012), masyarakat terdiri dari berbagai bagian yang saling memengaruhi satu dengan lainnya. Masyarakat terbentuk atas substruktursubstruktur yang dalam fungsi mereka masingmasing dan saling bergantung sehingga perubahan yang terjadi dalam fungsi satu bagian dalam substruktur akan memengaruhi substruktur lainnya, Setiap substruktur yang telah mantap akan menopang aktivitas-aktivitas atau substruktur lainnya. Keluarga merupakan unit utama dalam sebuah sistem. Keluarga merupakan unit terkecil dalam kehidupan sosial dan memiliki peran yang sangat besar dalam membentuk sumberdaya manusia yang berkualitas. Untuk mencapai keseimbangan sistem yang stabil dalam keluarga dan masyarakat, maka setiap keluarga harus berfungsi dengan baik.

Dalam sistem keluarga, fungsi dasar keluarga adalah menyediakan kondisi lingkungan yang sesuai bagi anggota keluarga agar aspek fisik, psikologis, sosial dan mental semua anggota keluarga dapat berkembang (Dai \& Wang, 2015). Keberfungsian keluarga mengacu pada bagaimana seluruh anggota keluarga dapat saling berkomunikasi satu sama lain, saling berkaitan satu sama lain, mempertahankan hubungan dan mengambil keputusan serta penyelesaian masalah bersama. Fungsi keluarga dapat dilihat sebagai suatu konsep multidimensi yang menggambarkan interaksi antar anggota keluarga dan secara bersamasama mencapai tujuan keluarga (Roman et al., 2015). Junko, Yuuri, Shota, dan Naohiro (2015) mendefinisikan fungsi keluarga sebagai aktivitas kognitif keluarga yang diperlihatkan melalui aktivitas keluarga dalam berinteraksi melalui peran anggota keluarga yang berkaitan dengan perilaku mereka terhadap lingkungan di dalam keluarga. Keluarga berperan dalam menciptakan stabilitas, pemeliharaan, kesetiaan dan dukungan bagi anggotanya. Selain itu, jika fungsi keluarga tidak dapat dilakukan dengan optimal maka akan timbul berbagai hal yang negatif baik bagi anggota keluarga maupun bagi masyarakat. Oleh karenanya, fungsi keluarga harus dijalankan dengan baik oleh setiap keluarga sehingga kesuksesan dan kebahagiaan pernikahan akan tercapai. Fungsi keluarga juga harus dijadikan sebagai pijakan dan tuntunan setiap keluarga dalam rangka mewujudkan keluarga sejahtera dan berkualitas. Fungsi keluarga harus dipahami dengan baik oleh semua keluarga maupun pasangan yang akan berkeluarga agar dapat menyiapkan dan menjalankannya dengan baik (Rochaniningsih, 2014). Ketika keluarga berfungsi dengan baik maka anggota keluarga dapat melakukan penyelesaikan masalah, mendukung satu sama lain, berkomunikasi efektif, dan menanggapi suatu tantangan yang timbul (Maulina dan Amalia, 2019).

Selama ini, pelaksanaan fungsi keluarga di Indonesia belum begitu optimal. Berdasarkan Survei RPJMN 2017, pemahaman dan kesadaran tentang fungsi keluarga masih rendah, yaitu sebesar 29,5 persen. Adapun kemungkinan penyebabnya adalah karena adanya masalah dan kesulitan yang dihadapi 
keluarga yang memengaruhi keberfungsian keluarga. Ketidakberfungsian keluarga akan menciptakan lingkungan keluarga menjadi tidak kondusif seperti kurang harmonisnya hubungan antar anggota keluarga, kurang kontrolnya orang tua terhadap perilaku anak serta kurangnya kehangatan dan dukungan antar anggota keluarga (Ahmed, 2015). Permasalahan lainnya yang berdampak pada ketidakberfungsian keluarga adalah faktor kemiskinan (Banovcinova, Levicka, \& Veres, 2014). Kemiskinan membawa dampak terhadap kehidupan keluarga, diantaranya pendapatan dan daya beli yang menurun yang berakibat tidak terpenuhinya pemenuhan kebutuhan akan pendidikan, kesehatan dan pangan. Berdasarkan data BPS (2018) persentase penduduk miskin pada September 2017 di Indonesia sebesar 10,2 persen. Jika dilihat berdasarkan wilayah, maka penduduk miskin di wilayah perdesaan masih lebih tinggi $(13,47$ persen) dibandingkan di perkotaan $(7,26$ persen).

Tidak hanya faktor kemiskinan, keanekaragaman budaya yang ada di Indonesia dapat memengaruhi nilai dan peran dalam sebuah keluarga (Siregar, 2016) meskipun faktor budaya juga dikhawatirkan dapat menghambat keluarga untuk berkembang. Sejumlah penelitian lain juga membuktikan bahwa fungsi keluarga dipengaruhi oleh struktur keluarga, latar belakang budaya, dan status sosial ekonomi keluarga (Banovcinova et al., 2014; Dai \& Wang, 2015). Faktor lain yang juga memengaruhi fungsi keluarga ialah faktor demografi (October, 2018), usia, status sosial ekonomi, pendidikan (Pamungkas, Chramroonsawasdi, \& Vatanasomboon, 2018), dan pendapatan (Ningsih \& Herawati, 2017).

Selain itu, pengetahuan mengenai jenis-jenis fungsi keluarga dapat memengaruhi pelaksanaan fungsi keluarga. Zamani, Nasir, Desa, Khairudin, dan Yusooff (2014) menemukan bahwa kemampuan kognitif seseorang berhubungan dengan fungsi keluarga. Hal ini bermakna bahwa semakin baik pengetahuan seseorang mengenai fungsi keluarga, maka akan semakin baik fungsi keluarga yang dilaksanakan. Pengetahuan adalah kemampuan untuk mengingat kembali sesuatu yang telah dipelajari termasuk hal spesifik dari hal yang dipelajari dan merupakan dasar dari domain-domain berikutnya. Pengetahuan merupakan dominan yang sangat penting dalam pembentukan tindakan atau perilaku seseorang (Notoatmojo, 2003). Pengetahuan keluarga ialah informasi yang dimiliki dan diingat oleh keluarga. Pengetahuan keluarga dapat diperoleh melalui materi-materi yang disampaikan pada pelatihan-pelatihan, sosialisasi maupun seminar (Wijayanti \& Berdame, 2015).

Akses informasi keluarga juga memengaruhi pelaksanaan fungsi keluarga. Sunarti (2015) menemukan bahwa akses informasi dan sumber informasi memiliki hubungan dengan fungsi keluarga. Semakin banyak akses informasi, sumber informasi, dan jenis informasi yang diperoleh keluarga maka semakin tinggi kemampuan keluarga untuk mengelola sumberdaya yang dimilikinya. Akses informasi ialah kemudahan keluarga dalam mendapatkan sumber informasi yang dibutuhkan. Akses informasi adalah sistem yang menggambarkan ketersediaan informasi bagi warga negara (Oltmann, 2009). Wijayanti dan Berdame (2015) menyatakan bahwa informasi yang dibutuhkan keluarga dapat dianalisis menggunakan indikator komunikasi yaitu who (siapa yang menyampaikan), say what (pesan yang disampaikan), in which channel (media yang digunakan), to whom (kepada siapa ditujukan), dan with what effect (efek/pengaruh). Akses informasi keluarga dapat diperoleh melalui peserta tokoh-tokoh penggerak di lingkungan masyarakat maupun para pemangku kebijakan yang memiliki akses luas dalam menyampaikan informasi ke masyarakat

Penelitian mengenai fungsi keluarga sudah banyak dilakukan di Indonesia, diantaranya penelitian yang mengaitkan fungsi keluarga dengan perlindungan anak (Fatimaningsih, 2013), perkembangan remaja (Rochaniningsih, 2014), penyesuaian perkawinan (Ningsih \& Herawati, 2017), dan kesejahteraan keluarga (Sunarti, Johan, \& Haryati, 2010). Penelitian lain juga meneliti fungsi keluarga pada keluarga orang tua tunggal (Syahmala, 2015) dan pasien rehabilitasi narkoba (Zamani et al., 2014). Beberapa penelitian terdahulu menggambarkan penemuan mengenai faktor-faktor yang berkaitan dengan fungsi keluarga (Boylu, Copur, \& Oztop, 2013; Hodge et al., 2012; Junko et al., 2015; Koutra et al., 2016; LorenzoBlanco, Unger, Baezconde-garbanati, Rittolson, \& Soto, 2012; Zabriskie, Aslan, \& Williamson, 2018).

Selain itu, penelitian tersebut dilakukan hanya terbatas pada suatu wilayah tertentu dan tidak banyak menjelaskan mengenai fungsi-fungsi apa saja yang paling dominan dilaksanakan oleh keluarga. Selama ini, belum ada penelitian mengenai faktor yang memengaruhi 
pelaksanaan fungsi keluarga khususnya delapan fungsi keluarga, yaitu fungsi agama, cinta kasih, sosial budaya, perlindungan, reproduksi, sosialisasi pendidikan, ekonomi dan lingkungan dengan responden dari berbagai latar belakang budaya dalam suatu negara.

Mengingat pentingnya pelaksanaan fungsi keluarga, maka analisis pelaksanaan fungsi keluarga sangat diperlukan terutama untuk mendapatkan gambaran faktor apa saja yang memengaruhi pelaksanaan fungsi keluarga di Indonesia. Peneliti menguji hipotesis bahwa terdapat pengaruh karakteristik sosial ekonomi keluarga, pengetahuan, dan akses informasi keluarga terhadap pelaksanaan fungsi keluarga. Penelitian ini bertujuan untuk mengidentifikasi karakteristik sosial ekonomi responden, akses informasi yang dimiliki responden, serta menganalisis pengaruh karakteristik sosial ekonomi dan akses informasi terhadap pelaksanaan fungsi keluarga di Indonesia.

\section{METODE}

Penelitian ini menggunakan desain cross sectional study, yaitu penelitian dilakukan pada satu waktu tertentu dengan menggunakan data sekunder yang bersumber dari modul keluarga Survei Indikator Kinerja Rencana Pembangunan Jangka Menengah Nasional (SRPJMN) Program KKBPK BKKBN Tahun 2017. Survei ini merupakan survei rutin tahunan yang dilakukan di seluruh provinsi Indonesia.

Populasi penelitian ini adalah rumah tangga yang masuk ke dalam daftar blok sensus BKKBN di seluruh provinsi di Indonesia. Contoh penelitian ini adalah keluarga yang masuk kriteria populasi penelitian dan diacak menggunakan teknik PPS (Probablitiy Proportional to Size). Responden dalam penelitian ialah istri dalam keluarga terpilih. Apabila istri tidak ada di rumah selama satu pekan, maka responden diganti menjadi suami. Pemilihan contoh dilakukan secara acak. Total partisipan dalam penelitian ini adalah 67.224 keluarga. Data sekunder dalam penelitian ini terdiri atas karakteristik keluarga (usia, kategori pendidikan, status pernikahan); pengetahuan responden keluarga, akses informasi, dan pelaksanaan fungsi keluarga yang diambil dari kuesioner keluarga SRPJMN BKKBN Tahun 2017.

Pengetahuan keluarga ialah informasi yang dimiliki dan diingat oleh keluarga. Pengetahuan keluarga didesain untuk mengukur aspek pengetahuan responden mengenai istilah delapan fungsi keluarga, kependudukan, program pembangunan keluarga, Keluarga Berencana, dan kesehatan reproduksi remaja. Variabel pengetahuan menggunakan skala Guttman meliputi keterangan $0=$ tidak dan $1=y a$. Nilai Cronbach's alpha untuk kuesioner pengetahuan ini adalah 0,860.

Akses informasi ialah kemudahan keluarga dalam mendapatkan sumber informasi yang dibutuhkan. Akses informasi diukur melalui sumber informasi melalui media yang diakses (radio, televisi, koran, majalah/tabloid, pamflet/leaflet/brosur, flipchart/lembar balik, poster, spanduk, banner, billboard/baliho, pameran, website/internet, mupen $\mathrm{KB}$, dan mural/lukisan dinding/grafity) dan petugas pemberi informasi (PLKB, guru, tokoh agama, tokoh masyarakat, Dokter, bidan/perawat. perangkat desa, dan PPKBD/Sub PPKBD/Kader) mengenai Kependudukan, Pembangunan Keluarga, KB, Kesehatan Reproduksi Remaja. Variabel jumlah media informasi ini terdiri atas pernyataan dengan skala Guttman meliputi keterangan $0=$ tidak dan $1=y a$. Nilai Cronbach's alpha untuk kuesioner akses informasi ini adalah 0,926.

Fungsi keluarga dalam penelitian ini meliputi fungsi agama, sosial budaya, cinta kasih, perlindungan, reproduksi, sosialisasi dan pendidikan, ekonomi, serta lingkungan. Masingmasing fungsi terdapat beberapa pernyataan sesuai dengan nilai-nilai yang mencerminkan pelaksanaan fungsi didalam keluarga. Variabel fungsi keluarga terdiri atas pernyataan dengan skala Guttman meliputi keterangan $0=$ tidak dan $1=y a$. Nilai Cronbach's alpha untuk kuesioner pelaksanaan fungsi keluarga ini adalah 0,831 .

Pada saat melakukan pengolahan data, variabel pengetahuan, akses informasi, dan fungsi keluarga beserta subvariabelnya diubah ke dalam bentuk rasio dengan menjumlahkan setiap jawaban hingga mendapatkan skor komposit. Setelah mendapatkan skor setiap variabel, selanjutnya skor diubah ke dalam bentuk indeks dan dikelompokkan. Skor indeks kemudian dikelompokkan menjadi 2 kategori yakni tinggi (indeks 60-100) dan rendah (indeks 0-60). Tingkat pendidikan dikelompokkan menjadi tiga kategori yakni rendah, sedang, dan tinggi. Status pernikahan dibagi ke dalam dua kategori yakni kategori cerai hidup/cerai mati/hidup berpasangan dan menikah.

Analisis data yang digunakan dalam penelitian ini meliputi analisis deskriptif dan inferensial. Untuk mengetahui sebaran jawaban dilakukan analisis deskriptif. Sementara itu, analisis 
inferensial yang digunakan adalah uji regresi linear berganda. Uji regresi dilakukan untuk menganalisis pengaruh karakteristik keluarga (usia, kategori pendidikan, status pernikahan); pengetahuan responden keluarga, akses informasi terhadap pelaksanaan fungsi keluarga. Model regresinya didefinisikan dalam persamaan berikut:

$\begin{aligned} Y= & \beta_{0}+\beta_{1} X_{1}+\beta_{2} X_{2}+\beta_{3} X_{3}+\beta_{4} X_{4}+\beta_{5} X_{5}+ \\ & \ldots \ldots .+\beta_{13} X_{13}+\beta_{14} X_{14}+\beta_{15} X_{15}+\varepsilon\end{aligned}$

Keterangan:

$\mathrm{Y}=$ Fungsi keluarga (skor index)

$\mathrm{X}_{1}=$ Umur (tahun)

$\mathrm{X}_{2}=$ Kategori Pendidikan

$\mathrm{X}_{3}=$ Status pernikahan (dummy variable)

$\mathrm{X}_{4}=$ Status pekerjaan (dummy variable)

$\mathrm{X}_{5}=$ Pengetahuan mengenai fungsi keluarga (skor indeks)

$\mathrm{X}_{6}=$ Pengetahuan mengenai kependudukan (skor indeks)

$\mathrm{X}_{7}=$ Jumlah media informasi mengenai kependudukan

$\mathrm{X}_{8}=$ Jumlah petugas yang memberikan informasi mengenai kependudukan

$\mathrm{X}_{9}=$ Pengetahuan mengenai kependudukan (skor indeks)

$\mathrm{X}_{10}=$ Jumlah media informasi mengenai $\mathrm{KB}$

$\mathrm{X}_{11}=$ Jumlah petugas yang memberikan informasi mengenai KB

$\mathrm{X}_{12}=$ Pengetahuan mengenai kesehatan reproduksi remaja (skor indeks)

$\mathrm{X}_{13}=$ Jumlah media informasi mengenai kesehatan reproduksi remaja

$\mathrm{X}_{14}=$ Jumlah petugas yang memberikan informasi mengenai kesehatan reproduksi remaja

$\mathrm{X}_{15}=$ Pengetahuan mengenai program pembangunan keluarga (skor indeks)

$\mathrm{X}_{16}=$ Jumlah media informasi mengenai program pembangunan keluarga

$\mathrm{X}_{17}=$ Jumlah petugas yang memberikan informasi mengenai program pembangunan keluarga

$\varepsilon \quad=$ Galat

HASIL

\section{Karakteristik Responden Keluarga}

Penelitian ini melibatkan 67.224 responden dengan berbagai karakteristik sosial ekonomi. Tabel 1 memperlihatkan proporsi jenis kelamin responden perempuan jauh lebih banyak dibandingkan laki-laki. Berdasarkan asal wilayah, lebih dari sebagian besar keluarga (61,9 persen) dalam penelitian ini bertempat tinggal di wilayah perdesaan.
Tabel 1 Persentase sebaran responden berdasarkan karakteristik sosial ekonomi

\begin{tabular}{|c|c|c|c|}
\hline Variabel & Kategori & $\mathrm{N}$ & $\%$ \\
\hline \multirow[t]{2}{*}{$\begin{array}{l}\text { Jenis } \\
\text { kelamin }\end{array}$} & Laki-laki & 11.229 & 16,7 \\
\hline & Perempuan & 55.995 & 83,3 \\
\hline \multirow{2}{*}{$\begin{array}{l}\text { Asal } \\
\text { wilayah }\end{array}$} & Perkotaan & 22.594 & 38,1 \\
\hline & Perdesaan & 41.631 & 61,9 \\
\hline \multirow[t]{7}{*}{ Usia } & 12-16 tahun & 54 & 0,1 \\
\hline & 17-25 tahun & 4.273 & 6,4 \\
\hline & 26-35 tahun & 15.336 & 22,8 \\
\hline & 36-45 tahun & 19.413 & 28,9 \\
\hline & 46-55 tahun & 15.892 & 23,6 \\
\hline & 56-65 tahun & 8.743 & 13,0 \\
\hline & $>65$ tahun & 3.513 & 5,2 \\
\hline \multirow[t]{4}{*}{$\begin{array}{l}\text { Status } \\
\text { pernikahan }\end{array}$} & Menikah & 60.010 & 89,3 \\
\hline & $\begin{array}{l}\text { Hidup bersama } \\
\text { pasangan }\end{array}$ & 813 & 1,2 \\
\hline & Cerai hidup & 1.600 & 2,4 \\
\hline & Cerai mati & 4.800 & 7,1 \\
\hline \multirow[t]{6}{*}{$\begin{array}{l}\text { Tingkat } \\
\text { pendidikan }\end{array}$} & $\begin{array}{l}\text { Tidak pernah } \\
\text { sekolah }\end{array}$ & 2.910 & 4,3 \\
\hline & SD & 29.096 & 43,3 \\
\hline & SLTP & 12.623 & 18,8 \\
\hline & SLTA & 16.196 & 24,1 \\
\hline & $\begin{array}{l}\text { D2/D2/D3/ } \\
\text { Akademi }\end{array}$ & 1.936 & 2,9 \\
\hline & Perguruan tinggi & 4.463 & 6,6 \\
\hline \multirow[t]{3}{*}{$\begin{array}{l}\text { Status } \\
\text { pekerjaan }\end{array}$} & Tidak bekerja & 34.972 & 52,0 \\
\hline & Bekerja & 32.252 & 48,0 \\
\hline & Total & 67.224 & 100,00 \\
\hline
\end{tabular}

Keterangan: $\mathrm{N}=$ jumlah responden; \%=persentase

Berdasarkan usia, proporsi responden terbanyak berada pada kategori usia dewasa akhir (36-45 tahun) yakni sebanyak 28,9 persen. Selain itu, terdapat responden yang berusia remaja awal (12-16 tahun) sebanyak 0,1 persen. Rata-rata usia responden dalam penelitian ini ialah 43,63 tahun. Sebagian besar responden memiliki status menikah $(89,3 \%)$. Hampir separuh (43,3 persen) responden keluarga berpendidikan rendah yaitu tamat Sekolah Dasar (SD). Menariknya, responden keluarga yang bekerja dan tidak bekerja tidak jauh berbeda proporsinya. Responden keluarga yang tidak bekerja atau sebagai ibu rumah tangga sedikit lebih tinggi dari yang bekerja, hanya berbeda empat persen.

\section{Pengetahuan Responden Keluarga mengenai 8 Fungsi Keluarga}

Sebagian besar $(84,4 \%)$ responden pernah mendengar/mengetahui mengenai fungsi keluarga. 


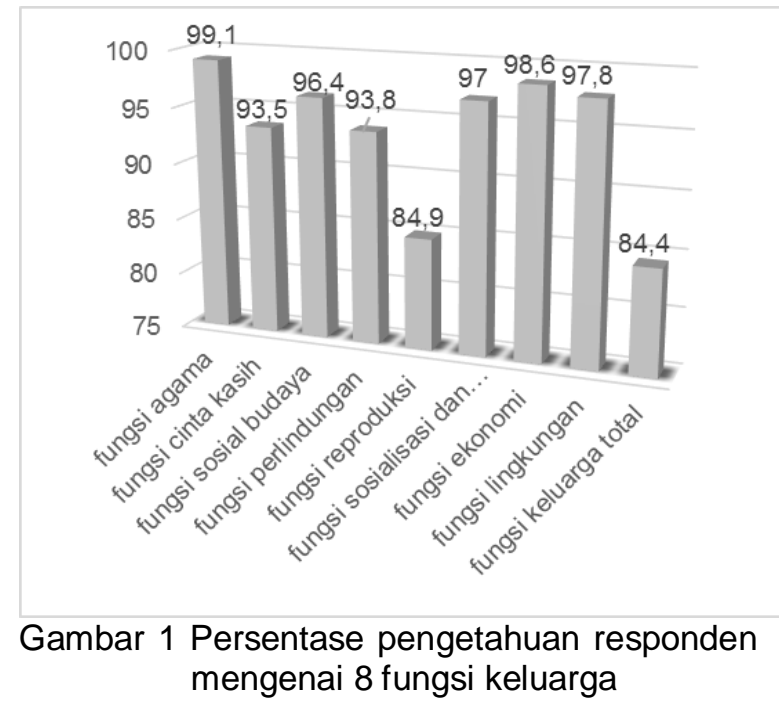

Hampir sebagian besar responden dalam penelitian ini memiliki pengetahuan mengenai fungsi keluarga dengan kategori tinggi yakni sebesar 97,7 persen. Dimensi fungsi keluarga yang paling banyak diketahui oleh responden ialah fungsi agama $(99,1 \%)$, fungsi ekonomi $(98,6 \%)$, dan fungsi lingkungan $(97,8 \%)$, sedangkan fungsi reproduksi $(94,9 \%)$ dan perlindungan $(93,8 \%)$ merupakan fungsi yang kurang banyak diketahui oleh keluarga (Gambar 1).

\section{Akses dan Media Informasi Keluarga mengenai Kependudukan, Program Pembangunan Keluarga (PK), Keluarga Berencana (KB), dan Kesehatan Reproduksi Remaja (KRR)}

Sebagian besar responden mengetahui informasi mengenai keluarga berencana $(85,4 \%)$ dan kesehatan reproduksi remaja $(75,0 \%)$.

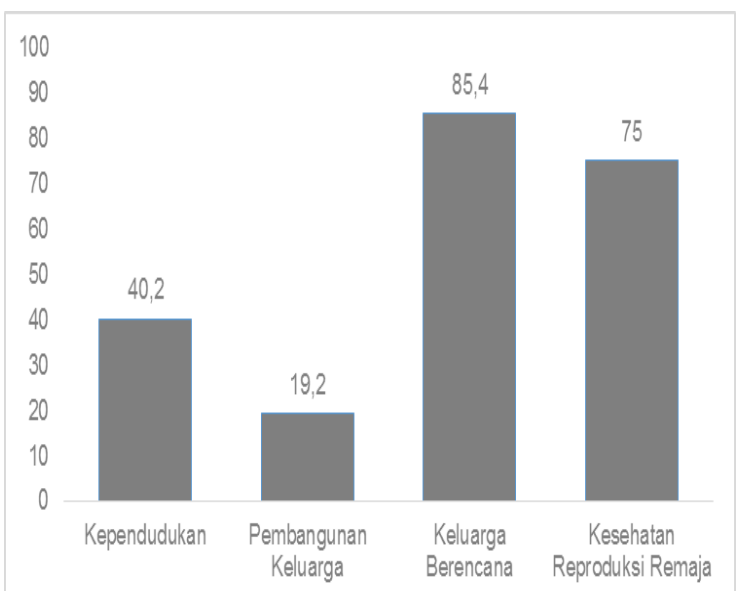

Gambar 2 Persentase pengetahuan responden mengenai kependudukan, pembangunan keluarga, KB dan kesehatan reproduksi remaja
Sementara itu, hampir separuh responden dalam penelitian ini memiliki pengetahuan mengenai kependudukan pada kategori tinggi yakni sebesar 40,2 persen. Pengetahuan mengenai program pembangunan keluarga dengan kategori tinggi baru mencapai 19,2 persen (Gambar 2).

Informasi yang paling banyak dibaca/dilihat/didengar oleh responden ialah informasi mengenai kependudukan, yaitu migrasi $(67,6 \%)$, kelahiran $(78,7 \%)$, kematian $(79,0 \%)$, kerusakan lingkungan $(69,0 \%)$, dan kemiskinan $(84,6 \%)$. Sementara itu, hanya sedikit $(4,7 \%)$ responden yang belum pernah membaca/melihat/mendengar informasi mengenai kependudukan. Responden paling banyak mendapatkan informasi mengenai kependudukan dari media televisi yakni 86,0 persen Sangat sedikit sekali responden yang mengetahui informasi kependudukan melalui media flipchart $(2,3 \%)$.

Hasil penelitian juga menemukan bahwa sebanyak tujuh persen responden tidak pernah mendengar atau mengetahui informasi mengenai kependudukan. Selain itu, hampir seluruh responden $(90,9 \%)$ mendapatkan informasi dari satu hingga delapan jenis media mengenai kependudukan. Jika dilihat berdasarkan petugas yang memberikan informasi, responden paling banyak mendapatkan informasi mengenai kependudukan dari tokoh masyarakat $(48,2 \%)$. Selanjutnya, sebanyak 20,5 persen responden tidak pernah mendapatkan informasi dari petugas mengenai kependudukan, namun lebih dari separuh responden $(69,4 \%)$ mendapatkan informasi mengenai kependudukan dari satu hingga empat orang petugas.

Informasi yang cukup banyak dibaca/dilihat/didengar oleh responden ialah informasi mengenai Program Pembangunan Keluarga (PK), yaitu program Bina Keluarga Balita $(42,9 \%)$, Bina Keluarga Lansia $(33,6 \%)$, dan Pusat Pelayanan Keluarga Sejahtera (26,6\%). Jumlah responden yang belum pernah membaca/melihat/mendengar informasi mengenai Program PK masih mencapai angka yang cukup tinggi yakni 47,0 persen. Media yang paling banyak memberikan informasi mengenai Program PK ialah media televisi sebanyak 30,4 persen, namun masih terdapat responden yang tidak pernah mendengar atau mengetahui informasi mengenai Program PK sebanyak 16,4 persen.

Sebagian besar responden (82,3\%) mendapatkan informasi dari satu hingga 
delapan jenis media mengenai Program PK. Jika dilihat dari petugas yang memberikan informasi, maka responden paling banyak mendapatkan informasi mengenai Program PK dari perangkat desa $(27,1 \%)$. Walaupun demikian masih terdapat enam persen responden yang tidak pernah mendapatkan informasi dari petugas mengenai Program PK. Sebagian besar responden (88,6\%) mendapatkan informasi mengenai Program PK dari satu hingga empat orang petugas.

Informasi mengenai keluarga berencana meliputi alat/cara $\mathrm{KB}$, sumber pelayananan $\mathrm{KB}$, slogan "ayo ikut KB", iklan alat KB Andalan. Responden paling banyak mendapatkan informasi mengenai KB melalui media televisi $(70,4 \%)$, spanduk $(33,5 \%)$, dan poster $(28 \%)$. Sangat sedikit sekali responden $(2,3 \%)$ yang mengetahui informasi KB melalui media flipchart. Sebanyak 7,1 persen responden tidak pernah mendengar atau mengetahui informasi mengenai KB. Selain itu, sebagian besar $(80,9$ $\%)$ mendapatkan informasi dari satu hingga delapan jenis media mengenai $\mathrm{KB}$. Jika dilihat dari petugasnya, maka lebih dari separuh keluarga yang diwawancara mendapatkan informasi mengenai KB dari bidan/perawat (58,0\%). Hanya 9,9 persen responden yang tidak pernah mendapatkan informasi dari petugas mengenai KB. Sebagian besar responden (87\%) mendapatkan informasi mengenai KB dari satu hingga empat orang petugas.

Informasi mengenai kesehatan reproduksi remaja (KRR) meliputi masa subur, umur kawin pertama, anemia, HIV/AIDS, dan NAPZA. Responden paling banyak mendapatkan informasi mengenai KRR dari televisi yakni sebanyak 66,0 persen. Sangat sedikit sekali $(2,8 \%)$ responden yang mengetahui informasi KRR melalui mupen KB. Walaupun demikian masih ditemukan 5,8 persen responden tidak pernah mendengar atau mengetahui informasi mengenai KRR.

Namun hampir semua responden (91,9\%) mendapatkan informasi dari satu hingga delapan jenis media mengenai KRR. Jika dilihat berdasarkan petugas yang memberikan informasi, maka responden paling banyak mendapatkan informasi mengenai KRR dari bidan/perawat sebanyak 34,1 persen. Sebanyak 17,2 persen responden tidak pernah mendapatkan informasi dari petugas mengenai $\mathrm{KRR}$, namun sebagian besar responden $(74,9 \%)$ mendapatkan informasi mengenai KRR dari satu hingga empat orang petugas.

\section{Pelaksanaan Fungsi Keluarga}

Fungsi keluarga dalam penelitian ini meliputi fungsi-fungsi pemenuhan kebutuhan fisik dan non fisik yang terdiri atas 8 fungsi yaitu, fungsi agama, fungsi sosial budaya, fungsi cinta kasih, fungsi perlindungan, fungsi reproduksi, fungsi sosialisasi dan pendidikan, fungsi ekonomi serta fungsi pembinaan lingkungan. Fungsi keluarga mempunyai makna masing-masing dan mempunyai peran penting dalam kehidupan keluarga. Secara keseluruhan, proporsi terbanyak pelaksanaan fungsi keluarga responden berada pada kategori rendah sebanyak 86.8 persen dan kategori tinggi sebanyak 13,2 persen.

Fungsi Agama menempatkan keluarga sebagai tempat pertama penanaman nilai-nilai keagamaan dan pemberi identitas agama pada setiap anak yang lahir. Keluarga mengajarkan seluruh anggotanya untuk melaksanakan ibadah dengan penuh keimanan dan ketaqwaan kepada Tuhan Yang Maha Esa. Berdasarkan hasil penelitian, proporsi terbanyak dari pelaksanaan fungsi agama berada pada kategori rendah sebanyak 88 persen dan kategori tinggi sebanyak 12 persen. Fungsi agama yang paling banyak dilaksanakan oleh responden ialah beribadah meliputi shalat, berdoa, puasa dan lainnya $(95,6 \%)$ dan berbuat baik seperti menolong orang lain $(44,8 \%)$. Selain itu, perilaku toleransi terhadap agama lain masih sedikit dilakukan $(28,8 \%)$.begitu pula dengan perilaku sabar dan ikhlas hanya dilakukan oleh 22,9 persen responden.

Fungsi Cinta Kasih menggambarkan bahwa keluarga harus menjadi tempat untuk menciptakan suasana cinta dan kasih sayang dalam kehidupan berkeluarga. Fungsi cinta kasih dapat diwujudkan dalam bentuk memberikan kasih sayang dan rasa aman serta memberikan perhatian diantara anggota keluarga. Berdasarkan hasil penelitian, proporsi terbanyak dari pelaksanaan fungsi cinta kasih berada pada kategori rendah $(90,3 \%)$ dan tinggi $(9,7 \%)$. Fungsi cinta kasih sudah mencapai 15,2 persen. Fungsi cinta kasih yang paling banyak dilaksanakan oleh responden ialah menunjukkan kasih sayang (62,4\%) dan menjaga keharmonisan keluarga (52,7\%). Selain itu, sikap saling percaya/setia baru dilakukan oleh 46,7 persen responden dan sifat tidak pilih kasih baru dilakukan oleh 41,4 persen responden.

Fungsi Sosial Budaya menunjukkan bahwa keluarga adalah wahana utama dalam 
pembinaan dan penanaman nilai-nilai luhur budaya bangsa. Keluarga menjadi tempat pertama anak dalam belajar berinteraksi dan beradaptasi dengan lingkungan sekitarnya serta belajar adat istiadat yang berlaku di sekitarnya. Berdasarkan hasil penelitian, proporsi terbanyak dari pelaksanaan fungsi sosial budaya berada pada kategori rendah $(84,8 \%)$ dan kategori tinggi (15,2\%). Fungsi sosial budaya yang paling banyak dilaksanakan oleh responden ialah gotongroyong $(59,2 \%)$ dan melestarikan budaya daerah/adat istiadat (43,9\%). Selain itu, perilaku musyawarah dan menghargai antar suku dan golongan masih sedikit dilakukan, yakni hanya 39,3 persen dan 32,6 persen.

Fungsi Perlindungan bermakna bahwa keluarga adalah tempat bernaung atau berlindung bagi seluruh anggotanya dan tempat untuk menumbuhkan rasa aman dan kehangatan. Keluarga melindungi setiap anggotanya dari tindakan-tindakan yang kurang baik sehingga anggota keluarga merasa nyaman dan aman. Berdasarkan hasil penelitian, proporsi terbanyak dari pelaksanaan fungsi perlindungan berada pada kategori rendah $(87,6 \%)$ dan kategori tinggi $(12,4 \%)$. Berdasarkan hasil penelitian, pelaksanaan fungsi perlindungan sudah mencapai 12,4 persen (Tabel 2).

Tabel 2 Persentase sebaran responden berdasarkan kategori fungsi keluarga

\begin{tabular}{llrr}
\hline \multicolumn{1}{c}{ Dimensi } & Kategori & \multicolumn{1}{c}{$\mathrm{n}$} & \multicolumn{1}{c}{$\%$} \\
\hline Fungsi agama & Rendah & 59.137 & 88,0 \\
& Tinggi & 8.087 & 12,0 \\
\hline Fungsi cinta kasih & Rendah & 60.682 & 90,3 \\
& Tingi & 6.542 & 9,7 \\
\hline Fungsi sosial budaya & Rendah & 56.978 & 84,8 \\
& Tinggi & 10.247 & 15,2 \\
\hline Fungsi perlindungan & Rendah & 58.882 & 87,6 \\
& Tinggi & 8.342 & 12,4 \\
\hline Fungsi reproduksi & Rendah & 62.649 & 93,2 \\
& Tinggi & 4.575 & 6,8 \\
\hline Fungsi sosialisasi & Rendah & 61.816 & 92,0 \\
pendidikan & Tinggi & 5.408 & 8,0 \\
\hline Fungsi ekonomi & Rendah & 56.735 & 84,4 \\
& Tinggi & 10.489 & 15,6 \\
\hline Fungsi lingkungan & Rendah & 61.585 & 91,6 \\
& Tinggi & 5.639 & 8,4 \\
\hline Fungsi keluarga total & Rendah & 58.350 & 86,8 \\
& Tinggi & 8.874 & 13,2 \\
\hline Total & & 67.224 & 100,0 \\
\hline Kel
\end{tabular}

Keterangan: $\mathrm{n}=$ jumlah responden; $\%=$ persentase
Fungsi perlindungan yang paling banyak dilaksanakan oleh responden ialah perlindungan kesehatan $(51,2 \%)$ dan perlindungan fisik (49,8\%). Fungsi perlindungan non fisik sudah dilakukan oleh 44,2 persen responden, begitu pula pemenuhan kebutuhan keluarga (sandang, pangan, dan papan) telah dilakukan oleh sebagian besar responden $(51,2 \%)$.

Fungsi Reproduksi memaknai keluarga menjadi pengatur reproduksi keturunan secara sehat dan berencana sehingga anak-anak yang dilahirkan menjadi generasi penerus yang berkualitas. Keluarga juga menjadi tempat memberikan informasi kepada anggotanya tentang hal-hal yang berkitan dengan seksualitas termasuk pendidikan seksualitas pada anak. Berdasarkan hasil penelitian, proporsi terbanyak dari pelaksanaan fungsi reproduksi berada pada kategori rendah $(93,2 \%)$ dan kategori tinggi (6,8\%).Fungsi reproduksi yang paling banyak dilaksanakan oleh responden ialah menghindari pergaulan bebas $(50,3 \%)$ dan menjaga kebersihan organ reproduksi (47,6\%). Selain itu, kegiatan memberikan informasi mengenai kesehatan reproduksi masih sedikit dilakukan $(29,2 \%)$, begitu pula dengan menikahkan anak pada usia ideal $(18,5 \%)$.

Fungsi Sosialisasi dan Pendidikan menunjukkan keluarga sebagai tempat utama dan pertama memberikan pendidikan kepada semua anak untuk bekal masa depan. Pendidikan yang diberikan oleh keluarga meliputi pendidikan untuk mencerdaskan dan membentuk karakter anak. Keluarga mensosialisasikan kepada anaknya tentang nilai, norma, dan cara untuk berkomunikasi dengan orang lain, mengajarkan tentang hal-hal yang baik dan buruk maupun yang salah dan yang benar. Berdasarkan hasil penelitian, proporsi terbanyak dari pelaksanaan fungsi sosialisasi dan pendidikan berada pada kategori rendah (92\%) dan kategori tinggi (8\%). Fungsi sosialisasi dan pendidikan yang paling banyak dilaksanakan oleh responden ialah menyekolahkan/mengkursuskan anak (80\%) dan mengajarkan anak untuk mandiri, bertanggung jawab, dan dapat bekerjasama sebanyak 44,3 persen. Menjadi panutan/contoh telah dilakukan oleh 40,1 persen responden. Selain itu, kegiatan melatih kreativitas hanya dilakukan oleh 15,7 persen responden.

Fungsi Ekonomi menggambarkan keluarga sebagai tempat utama dalam membina dan menanamkan nilai-nilai yang berhubungan dengan keuangan dan pengaturan penggunaan 
keuangan untuk memenuhi kebutuhan hidup dan mewujudkan keluarga sejahtera. Keluarga sebagai tempat untuk memperoleh makanan, pakaian, tempat tinggal, dan kebutuhan materi lainnya serta memberikan dukungan finansial kepada anggotanya.

Berdasarkan hasil penelitian, proporsi terbanyak dari pelaksanaan fungsi ekonomi berada pada kategori rendah $(84,4 \%)$ dan kategori tinggi (15,6\%). Fungsi ekonomi yang paling banyak dilaksanakan oleh responden ialah menabung $(90,3 \%)$ dan hemat atau tidak boros (68,1\%). Sebanyak 43,1 persen responden memilki sifat ulet/kerja keras. Selain itu, memilih kebutuhan sesuai prioritas hanya dilakukan oleh 36,5 persen responden.

Fungsi Pembinaan Lingkungan menjelaskan bahwa keluarga memiliki peran mengelola kehidupan dengan tetap memelihara lingkungan di sekitarnya. Keluarga dan anggotanya harus mengenal tetangga dan masyarakat di sekitar serta peduli terhadap kelestarian lingkungan alam. Berdasarkan hasil penelitian, proporsi terbanyak dari pelaksanaan fungsi pembinaan lingkungan berada pada kategori rendah $(91,6 \%$ dan kategori tinggi $(8,4 \%)$. Fungsi pembinaan lingkungan yang paling banyak dilaksanakan oleh responden ialah membersihkan lingkungan sekitar (76,3\%) dan tidak membuang sampah sembarangan (68,9\%). Sementara, kegiatan melestarikan lingkungan (penghijauan) hanya dilakukan oleh 25 persen responden, begitu pula dengan perilaku hemat energi yang hanya dilakukan oleh 18,2 persen responden.

\section{Faktor yang Memengaruhi Pelaksanaan Fungsi Keluarga}

Tabel 3 menunjukkan bahwa pengaruh variabel terhadap pelaksanaan fungsi keluarga memiliki koefesien determinasi sebesar 0,225. Hal ini mengindikasikan bahwa 22,5 persen pengaruh pelaksanaan fungsi keluarga responden dapat dijelaskan oleh variabel yang ada dalam model penelitian, sedangkan sisanya 77,5 persen dipengaruhi oleh variabel lain yang tidak ada dalam model penelitian.

Tabel 3 Koefesien regresi untuk menganalisis pengaruh karakteristik responden. pengetahuan responden. dan akses informasi terhadap pelaksanaan fungsi keluarga $(n=67.224)$

\begin{tabular}{|c|c|c|c|}
\hline \multirow[t]{2}{*}{ Variabel } & \multicolumn{3}{|c|}{$\begin{array}{l}\text { Pelaksanaan Fungsi } \\
\text { Keluarga }\end{array}$} \\
\hline & $\mathrm{B}$ & Beta & Sig. \\
\hline Konstanta & 20,177 & & 0,000 \\
\hline Umur (tahun) & 0,044 & 0,032 & $0,000^{* *}$ \\
\hline Kategori pendidikan ( $1=$ rendah. $2=$ menengah. $3=$ tinggi) & 0,938 & 0,036 & $0,000^{* *}$ \\
\hline $\begin{array}{l}\text { Status perkawinan (dummy } 0=\text { cerai hidup/cerai mati/hidup berpasangan, } \\
1=\text { menikah) }\end{array}$ & 1,354 & 0,024 & $0,000^{* *}$ \\
\hline Status pekerjaan (dummy $0=$ tidak bekerja, 1 = bekerja) & 1,941 & 0,056 & $0,000^{* *}$ \\
\hline Pengetahuan mengenai fungsi keluarga & 5,365 & 0,113 & $0,000^{* *}$ \\
\hline Pengetahuan mengenai kependudukan (skor indeks 0-100) & 0,118 & 0,200 & $0,000^{* *}$ \\
\hline Jumlah media informasi mengenai kependudukan (jumlah) & $-0,010$ & $-0,009$ & 0,161 \\
\hline Jumlah petugas yang memberikan informasi mengenai kependudukan & $-0,005$ & $-0,006$ & 0,221 \\
\hline $\begin{array}{l}\text { Pengetahuan mengenai program KB (dummy } 0=\text { tidak mengetahui, } 1= \\
\text { mengetahui) }\end{array}$ & 1,649 & 0,025 & $0,000^{* *}$ \\
\hline Jumlah media informasi mengenai program KB & 0,042 & 0,044 & $0,000^{* *}$ \\
\hline Jumlah petugas yang memberikan informasi mengenai program KB & 0,026 & 0,036 & $0,014^{*}$ \\
\hline $\begin{array}{l}\text { Pengetahuan mengenai program Kesehatan Reproduksi Remaja (dummy } \\
0=\text { tidak mengetahui, } 1=\text { mengetahui) }\end{array}$ & $-0,423$ & $-0,006$ & 0,109 \\
\hline Jumlah media informasi mengenai KRR & 0,062 & 0,059 & $0,000^{* *}$ \\
\hline Jumlah petugas yang memberikan informasi mengenai KRR & 0,071 & 0,096 & $0,000^{* *}$ \\
\hline $\begin{array}{l}\text { Pengetahuan mengenai program pembangunan keluarga (skor indeks } 0 \text { - } \\
\text { 100) }\end{array}$ & 0,010 & 0,019 & $0,000^{* *}$ \\
\hline Jumlah media informasi mengenai program pembangunan keluarga & 0,050 & 0,038 & $0,000^{* *}$ \\
\hline $\begin{array}{l}\text { Jumlah petugas yang memberikan informasi mengenai program } \\
\text { pembangunan keluarga }\end{array}$ & 0,053 & 0,067 & $0,000^{* *}$ \\
\hline Adj. $R^{2}$ & & 0,227 & \\
\hline $\mathrm{F}$ & & 1159,042 & \\
\hline Sig. Model & & $0,000^{* *}$ & \\
\hline
\end{tabular}

Keterangan: ${ }^{* *}$ signifikan pada $p \leq 0,01$; * signifikan pada $p \leq 0,05$ 
Berdasarkan hasil analisis regresi diperoleh bahwa faktor yang siginifikan memengaruhi pelaksanaan fungsi keluarga adalah usia, tingkat pendidikan, status perkawinan, status pekerjaan, pengetahuan mengenai fungsi keluarga, pengetahuan mengenai kependudukan, jumlah media informasi, dan jumlah petugas yang memberikan informasi mengenai keluarga. Pengetahuan mengenai kependudukan memiliki pengaruh yang paling besar terhadap pelaksanaan fungsi keluarga dengan nilai Beta 0,209.

Hasil analisis menunjukkan bahwa pelaksanaan fungsi keluarga dipengaruhi secara signifikan positif oleh usia, status perkawinan, status pekerjaan, tingkat pendidikan, pengetahuan mengenai fungsi keluarga, akses informasi, dan jumlah petugas yang memberikan infomasi. Pelaksanaan fungsi keluarga meningkat dengan semakin bertambahnya usia responden. Hasil penelitian menunjukkan bahwa semakin bertambah usia responden setiap tahun akan meningkatkan skor fungsi keluarga sebanyak 0,044 poin.

Skor pelaksanaan fungsi keluarga pada keluarga dengan status menikah lebih besar dibandingkan dengan keluarga yang bercerai dan hidup bersama pasangan, yakni sebesar 1,354 poin. Pada keluarga dengan kategori pendidikan yang lebih tinggi, skor fungsi keluarga lebih besar sebanyak 0,938 poin dibandingkan keluarga dengan kategori pendidikan yang lebih rendah tingkatannya. Skor pelaksanaan fungsi keluarga pada responden yang berstatus bekerja lebih besar dibandingkan dengan responden yang tidak bekerja yakni sebesar 1,941 poin.

Pengetahuan responden mengenai fungsi keluarga, kependudukan, keluarga berencana dan program pembangunan keluarga memberikan pengaruh yang signifikan positif terhadap fungsi keluarga secara berturut-turut dengan peningkatan poin fungsi keluarga sebesar 5,$365 ; 0,118 ; 1,649$; dan 0,010. Akses informasi berupa sumber informasi dan jumlah petugas yang memberikan informasi juga memberikan pengaruh yang signifikan positif terhadap pelaksanaan fungsi keluarga. Setiap kenaikan jumlah media informasi program KB, kesehatan reproduksi, dan program pembangunan keluarga akan meningkatkan fungsi keluarga secara berturut-turut sebesar 0,$042 ; 0,062$; dan 0,050. Setiap penambahan jumlah petugas yang memberikan informasi mengenai KB, kesehatan reproduksi, dan program pembangunan keluarga akan meningkatkan pelaksanaan fungsi keluarga secara sebesar 0,042;0,071;0,053. Hal ini menunjukkan bahwa akses informasi memberikan pengaruh yang positif terhadap pelaksanaan fungsi keluarga.

\section{PEMBAHASAN}

Hasil penelitian ini menunjukan adanya pengaruh karakteristik sosial ekonomi, pengetahuan, dan akses informasi terhadap pelaksanaan fungsi keluarga. Hasil ini mendukung penelitian-penelitian sebelumnya yang juga memperlihatkan adanya pengaruh beberapa variabel seperti karakteristik sosial ekonomi terhadap pelaksanaan fungsi keluarga (Banovcinova et al., 2014). Tidak hanya itu, JihYuan, Mary-Jo, Yong-Yuan, Yea-Ying, dan Chiung-Ying (2014) juga menemukan bahwa faktor demografi, pendapatan, status keluarga dan status pernikahan berpengaruh terhadap fungsi keluarga. Bahkan faktor usia dan pekerjaan sangat berkaitan dengan fungsi keluarga (Junko et al., 2015).

Hasil penelitian menunjukkan usia responden memiliki pengaruh yang positif terhadap fungsi keluarga. Hasil ini sesuai dengan penelitian October (2018) dan Pamungkas et al. (2018) yang menemukan bahwa usia memiliki pengaruh terhadap fungsi keluarga. Hal ini menunjukkan bahwa pada setiap terjadi penambahan usia responden akan membuat fungsi keluarga semakin baik. Kategori usia responden didominasi oleh kategori usia dewasa menengah (35-55 tahun). Usia ini menunjukkan bahwa responden dapat bersikap lebih bijak dan matang secara emosi dalam menempatkan peran dan fungsinya di dalam keluarga. Selain itu, orang yang memasuki usia dewasa menengah telah mampu untuk mencapai keseimbangan antara pekerjaan dan tanggung jawab relasi di tengah-tengah perubahan fisik dan psikologis yang berlangsung seiring dengan proses penuaan. Pada usia ini seseorang membuat pilihan apa yang akan dilakukan, cara menginvestasikan waktu dan sumber daya, mengevaluasi aspekaspek dalam kehidupan yang hendak dirubah (Lachman, 2004). Dengan sifat yang demikian, maka responden pada usia ini akan lebih dapat mengoptimalkan fungsi keluarganya.

Responden yang memiliki pekerjaan memiliki skor fungsi keluarga yang lebih tinggi dibandingkan responden yang tidak bekerja. Responden yang bekerja biasanya memiliki pendapatan yang lebih besar dibandingkan responden yang tidak bekerja. Hasil penelitian Boylu et al. (2013) menunjukkan bahwa keluarga dengan suami istri bekerja memiliki 
fungsi keluarga yang lebih baik dibandingkan keluarga yang hanya suami yang bekerja. Suami istri yang bekerja memungkinkan untuk menghasilkan pendapatan yang lebih baik. Pendapatan merupakan salah satu faktor yang memengaruhi fungsi keluarga (Banovcinova et al., 2014; Jih-Yuan et al., 2014). Hasil penelitian menunjukkan bahwa sebagian besar responden menerapkan perilaku menabung dalam keluarganya. Perilaku ini menunjukkan bahwa keluarga lebih mampu untuk memenuhi kebutuhan keluarga berupa kebutuhan pangan sandang dan papan jika istri membantu suami bekerja. Dengan demikian, fungsi ekonomi erat kaitannya dengan fungsi lain yang menjadi bagian dari fungsi keluarga. Selain itu, masalah pemenuhan ekonomi dapat mengakibatkan ketidakberfungsian keluarga (Raharjo, Puspitawati, \& Krisnatuti, 2015).

Selain karakteristik keluarga, hasil analisis menunjukan bahwa sebagian besar responden memiliki pengetahuan mengenai delapan dimensi fungsi keluarga dan kependudukan pada kategori tinggi. Selain itu, secara keseluruhan pelaksanaan fungsi keluarga belum terlaksana secara optimal. Dominasi keluarga yang tinggal di perdesaan, memiliki pendidikan yang rendah, berstatus menikah dan bekerja sebagai ibu rumah tangga memengaruhi pelaksanaan fungsi keluarga. Sebanyak 61,9 persen responden berasal dari pedesaan dan sebagian besar responden berstatus menikah (89,3\%). Sekitar 43,3 persen responden merupakan tamatan Sekolah Dasar (SD). Sebanyak 52,0 persen sebagai ibu rumah tangga. Tingkat pendidikan yang rendah dapat mengakibatkan responden memiliki pendapatan yang juga rendah. Pendapatan yang rendah dapat menyebabkan keberfungsian keluarga menjadi bermasalah karena kondisi keuangan yang tidak aman berkaitan erat dengan kemampuan untuk menyelesaikan masalah dan menghambat kohesi dalam keluarga (Banovcinova et al., 2014). Herzer et al. (2010) juga menyatakan bahwa rendahnya pemasukan keluarga berpengaruh pada buruknya keberfungsian keluarga.

Sebagian besar responden mengetahui mengenai KB dan kesehatan reproduksi remaja. Sumber informasi mengenai kependudukan, KB, KRR, dan Program Pembangunan Keluarga paling banyak diketahui oleh responden melalui media televisi. Informasi tersebut banyak diperoleh dari tokoh masyarakat, bidan/perawat, dan perangkat desa. Keluarga berencana dan kesehatan reproduksi remaja sudah banyak dikenal oleh masyarakat karena gencarnya sosialisasi yang dilakukan oleh pemerintah. Hasil ini menggambarkan bahwa pengetahuan responden keluarga cukup baik, yang diperoleh melalui media televisi, tokoh masyarakat dan aparat desa.

Secara umum, pelaksanaan fungsi keluarga belum terlaksana secara optimal. Dimensi fungsi keluarga yang cukup banyak terlaksana ialah fungsi ekonomi. Sementara, dimensi fungsi reproduksi termasuk ke dalam kategori pencapaian terendah. Hal ini menunjukkan bahwa keluarga baru bisa berfokus pada tugas dasar saja, yakni hanya berfokus pada pemenuhan kebutuhan keluarga dalam sandang dan pangan, sementara pemenuhan tugas krisis berkaitan dengan kesehatan resproduksi belum dilaksanakan secara optimal. Hasil penelitian Wijayanti dan Berdame (2019) menunjukkan hal serupa, yakni fungsi reproduksi dalam keluarga belum dilaksanakan secara optimal. Seharusnya, agar fungsi keluarga dapat terlaksana, keluarga harus mampu memenuhi serangkaian tugas, meliputi tugas dasar (memenuhi kebutuhan dasar keluarga berupa sandang, pangan dan papan), tugas perkembangan (seperti adaptasi dan dukungan untuk pertumbuhan dan perkembangan anggota keluarga), dan tugas krisis (seperti mengatasi beragam kedaruratan dalam keluarga) (Dai \& Wang, 2015).

Hasil penelitian menunjukkan bahwa status pernikahan responden memiliki pengaruh yang positif terhadap fungsi keluarga. Hal ini sejalan dengan penelitian Jih-Yuan et al. (2014) dan Yang dan Hong (2015) yang menemukan bahwa status pernikahan memiliki pengaruh terhadap keberfungsian keluarga. Al-Krenawi, Graham, dan Al-Gharaibeh (2011) dan Dai dan Wang (2015) juga menyatakan bahwa struktur keluarga dapat memengaruhi fungsi keluarga.

Hasil analisis menunjukkan bahwa terdapat banyak responden dengan status menikah. Fungsi keluarga akan berjalan optimal apabila peran keluarga dapat dilakukan secara seimbang. Pada keluarga yang hanya dikepalai oleh ibu, fungsi keluarga tidak dapat berjalan lebih lancar dibandingkan keluarga yang lengkap memiliki ayah dan ibu yang berperan di bidang domestik dan publik. Syahmala (2015) menemukan bahwa, orang tua single parent harus bekerja guna untuk memenuhi kebutuhan ekonomi keluarganya serta membagi waktu antara pekerjaan dan merawat anak. Keterbatasan ini tentunya menjadi resiko bagi keluarga yang tidak utuh untuk bisa memenuhi pencapaian fungsi keluarganya secara optimal dikarenakan orang tua hanya dapat 
mengoptimalkan fungsi ekonomi saja. Kerjasama antara ayah dan ibu akan membentuk sinergi dalam pencapaian tujuan keluarga sehingga keluarga dapat menjalankan fungsinya dengan baik. Fungsi ekonomi akan lebih optimal pada keluarga yang utuh, karna dapat dimungkinkan ayah dan ibu bekerjasama dalam menjalankan fungsi ekonomi. Fungsi agama juga dapat lebih optimal pada keluarga yang utuh, anak laki-laki akan menjadikan ayah sebagai role model dan anak perempuan akan menjadikan ibu sebagai contoh dalam menjalankan ibadah sehari-hari. Fungsi reproduksi juga akan lebih optimal apabila anak mendapatkan sosialiasi dari ayah dan ibu. Sinergisme antara ayah dan ibu tentunya akan lebih optimal dalam membangun visi dan misi keluarga termasuk fungsi keluarga di dalamnya.

Responden dengan tingkat pendidikan yang lebih tinggi memiliki fungsi keluarga yang lebih besar dibandingkan responden yang memiliki tingkat pendidikan yang lebih rendah. Hal ini diperkuat dengan hasil penelitian Boylu et al. (2013); Pamungkas et al. (2018); dan October (2018) yang menyatakan bahwa pendidikan memiliki pengaruh terhadap fungsi keluarga. Proporsi tertinggi pendidikan reponden berada pada kategori lulus SLTA. Hal ini menunjukkan bahwa responden berada pada kategori pendidikan yang cukup baik. Hal ini tentunya berkaitan erat dengan pemahaman responden mengenai fungsi keluarga. Responden dengan pendidikan yang tinggi akan lebih memahami peran dan fungsi yang harus dijalankan dalam keluarga.

Castillo-Diaz dan Padilla (2013) menyatakan bahwa kondisi kognitif memengaruhi fungsi keluarga. Sunarti et al. (2010) juga menyatakan bahwa semakin tinggi tingkat pendidikan maka cara berpikirnya akan semakin baik sehingga mampu mengajarkan anggota keluarganya untuk dapat menjalankan peran dan fungsinya masing-masing di dalam keluarga.

Hasil lainnya menunjukan bahwa pengetahuan memberikan pengaruh yang positif terhadap fungsi keluarga. Pengetahuan seseorang mengenai fungsi keluarga dapat memengaruhi pelaksanaan fungsi keluarga. Semakin baik pengetahuan responden maka akan semakin baik pelaksanaan fungsi keluarganya. Responden yang memiliki pengetahuan yang baik tentunya akan memiliki kesadaran yang lebih tinggi untuk dapat mengaplikasikan pengetahuan yang dimilikinya. Zamani et al. (2014) menyatakan bahwa, semakin baik kemampuan kognitif seseorang maka akan semakin baik pula fungsi dan kelentingan keluarga. Hal ini menunjukkan bahwa semakin tinggi pengetahuan seseorang maka akan semakin baik fungsi keluarganya.

Sumber informasi dan jumlah petugas yang memberikan infomasi juga memberikan pengaruh yang positif terhadap fungsi keluarga. Ini menunjukan bahwa akses informasi memberikan pengaruh yang positif terhadap fungsi keluarga. Semakin banyak akses informasi yang dimiliki keluarga maka akan semakin baik pelaksanaan fungsi keluarga. Hal ini sesuai dengan pernyataan Peter dan Olson (1999) yang menyatakan bahwa informasi yang dimiliki akan menciptakan sebuah penilaian dan persepsi penilaian terhadap suatu aspek atau perilaku yang tinggi pula.

Sunarti et al. (2010) juga menyatakan bahwa akses informasi dan sumber informasi memiliki hubungan yang positif dengan fungsi keluarga. Hasil penelitian menunjukkan bahwa pendidikan responden termasuk ke dalam kategori yang baik. Terdapat sejumlah responden yang mengenyam pendidikan hingga ke perguruan tinggi. Hal ini tentunya memungkinkan akses informasi yang tinggi bagi responden. Dengan akses informasi yang tinggi, maka akan lebih mudah bagi responden untuk dapat mengetahui apa saja programprogram dan pengetahuan yang berkaitan dengan keluarga sehingga responden dapat menerapkan fungsi keluarganya dengan baik.

\section{SIMPULAN DAN SARAN}

Berdasarkan hasil penelitian ini, dapat disimpulkan bahwa sebagian besar responden pernah mendengar/mengetahui mengenai 8 fungsi keluarga, memiliki pengetahuan mengenai delapan fungsi keluarga dan kependudukan pada kategori tinggi. Selain itu, pengetahuan mengenai Program Pembangunan Keluarga dengan kategori tinggi masih belum tercapai secara optimal. Sebagian besar responden memiliki pengetahuan mengenai KB dan kesehatan reproduksi remaja. Sumber informasi mengenai kependudukan, KB, KRR, dan Program PK paling banyak diketahui oleh responden melalui media televisi. Informasi tersebut banyak diperoleh dari tokoh masyarakat, bidan/perawat, dan perangkat desa. Pencapaian keberhasilan tertinggi pelaksanaan fungsi keluarga berdasarkan dimensi banyak tercapai pada dimensi fungsi ekonomi. Sementara, pelaksanaan fungsi keluarga yang masih sangat minim ialah fungsi reproduksi. Secara keseluruhan, fungsi keluarga belum terlaksana secara optimal sehingga dibutuhkan 
evaluasi terhadap pelaksanaan fungsi keluarga. Keluarga yang tinggal di perdesaan memiliki fungsi keluarga yang lebih baik dibandingkan dengan keluarga yang tinggal di perkotaan. Usia responden, tingkat pendidikan responden, pengetahuan responden, dan akses informasi memiliki pengaruh terhadap pelaksanaan fungsi keluarga.

Hasil temuan dalam penelitian ini terbatas pada variabel karakteristik sosial ekonomi keluarga, pengetahuan dan akses informasi yang dikaitkan dengan fungsi keluarga sehingga penjelasan model terbatas pada beberapa variabel yang diteliti. Penelitian ini juga didominasi oleh responden yang berasal dari pedesaan dengan status pekerjaan ibu rumah tangga. Penelitian ini juga lebih banyak melibatkan perempuan sebagai responden penelitian. Sehingga perlu adanya penelitian lebih lanjut dan mendalam dengan menganalisis faktor-faktor lain dan melibatkan responden keluarga dengan karakteristik yang lebih beragam.

Untuk dapat mendukung optimalisasi fungsi keluarga, pemerintah/instansi/stakeholder terkait harus mensosialisasikan secara intens mengenai fungsi keluarga kepada keluargakeluarga terutama yang tinggal di perkotaan, keluarga pasangan usia muda, dan keluarga dengan tingkat pendidikan rendah sebagai sasaran utama program. Pemerintah/instansi/stakeholder terkait dapat menyusun kembali sarana dan prasana yang efektif dan efisien bagi masyarakat di era digital seperti penggunaan jejaring media sosial dalam upaya optimalisasi fungsi keluarga. Penelitian selanjutnya perlu memasukkan variabel lain yang memengaruhi fungsi keluarga yaitu sumber daya keluarga, dukungan keluarga, perkembangan keluarga, penyesuaian perkawinan pada beragam sturktur keluarga yang ada di Indonesia. Sehingga hasilnya diharapkan dapat secara detail menjelaskan pengaruh budaya terhadap fungsi keluarga.

\section{DAFTAR PUSTAKA}

[BKKBN] Badan Koordinasi Keluarga Berencana Nasional. (2018). Kuatkan 8 Fungsi Keluarga untuk Kesejahteraan Indonesia. Jakarta, ID: BKKBN.

[BPS] Badan Pusat Statistik. (2018). Presentasi Penduduk Miskin September 2017 (Berita Resmi Statistik). Jakarta, ID: BPS.

Al-Krenawi, A., Graham, J. R., \& Al-Gharaibeh, F. (2011). A comparison study of psychological, family function marital and life satisfactions of polygamous and monogamous women in Jordan. Community Ment Health Journal, 47(5), 594-602. doi:10.1007/s10597-011-9405-x.

Banovcinova, A., Levicka, J., \& Veres, M. (2014). The impact of poverty on the family system functioning. Procedia-Social and Behavioral Science, 132, 148-153. doi:10.1016/j.sbspro.2014.04.291.

Boylu, A. A., Copur, Z., \& Oztop, H. (2013). Investigation of the factors influencing family function style. International Journal of Research in Business and Social Science, 2(3), 26-40. doi:10.20525/ ijrbs.v2i3.69.

Castillo-Diaz, M., \& Padilla, J. L. (2013). How cognitive interviewing can provide validity evidence of the response processes to scale items. Social Indicators Research, 114(3), 963-975. doi:10.1007/s11205-0120184-8.

Dai, L. \& Wang, L. (2015). Review of family functioning. Journal of Social Sciences, 3(12),134-141. doi:10.4236/jss.2015 .312014 .

Dewi, K. S., \& Ginanjar, A. S. (2019). Peranan faktor-faktor interaksional dalam perspektif teori sistem keluarga terhadap kesejahteraan keluarga. Jurnal Psikologi, 18(2), 245-263. doi:10.14710/jp.18.2.245263.

Fahrudin, A. (2012). Keberfungsian keluarga: Pemahaman konsep dan indikator pengukuran dalam penelitian. Jurnal Permasalahan dan Kesejahteraan Usaha Sosial, 17(02), 75-81. doi:10.33007 /inf.v17i2.94.

Fatimaningsih, E. (2013). Memahami fungsi keluarga dalam perlindungan anak. Jurnal Sosiologi, 17(2), 77-88.

Freed, R. D., Rubenstein, L. M., Daryanani, I., Olino, T. M., \& Alloy, L. B. (2016). The relationship between family functioning and adolescent depressive symptoms: The role of emotional clarity. Journal of Youth and Adolescence, 45(3), 505519. doi:10.1007/s10964-016-0429-y.

Henneberger, A. K., Durkee, M. I., Truong, N., Atkins, A., \& Tolan, P.H. (2016). The longitudinal relationship between peer violence and popularity and delinquency in adolescent boys: Examining effects by family functioning. Journal of Youth and Adolescence, 42(11), 16511660. doi:10.1007/s10964-012-9859-3. 
Herzer, M., Godiwala, N., Hommet, K. A., Drisscoll, K., Mitchell, M., PiazzaWaggoner, C., Zeller, M. H., \& Modi, A. C. (2010). Family functioning in the context of pediatric chronic conditions. Journal Development Behaviour Pediatric, 31(1), 1-14. doi:10.1097/DBP.0b013e318 $1 c 7226 b$.

Hodge, C. J., Zabriskie, R. B., Fellingham, G., Coyne, S., Lundberg, N. R., PadillaWalker, L. M., \& Day, R. D. (2012). The relationship between media in the home and family functioning in context of leisure. Journal of Leisure Research, 44(3), 285307. doi:10.1080/00222216.2012.1195026 6.

Jih-Yuan, C., Mary-Jo, C., Yong-Yuan, C.,YeaYing, L., \& Chiung-Ying, C. (2014). Factors affecting perceptions of family function in caregivers of children with attention deficit hyperactivity disorders. The Journal of Nursing Research, 22(3), 165-175. doi:10.1097/jnr.0000000000000042.

Junko, H, Yuuri, N., Shota, K., \& Naohiro, H. (2015). Factors affecting the perception of family functioning among couples in childrearing japanese families. Open Journal of Nursing, 5(5), 407-415. doi:10.4236/ojn.2015.55044.

Koutra, K., Triliva, S., Roumeliotaki, T., Basta, M., Lionis, C., \& Vgontzas, A. N. (2016). Family functioning in first-episode and chronic psychosis: The role of patient's symptom severity and psychosocial functioning. Community Mental Health Journal, 52(6), 710-723. doi:10.1007/ s10597-015-9916-y.

Lachman, M. E. (2004). Development in midlife. Annual Review Psychology, 55(1), 305331. doi:10.1146/annurev.psych.55. 090902.141521.

Lorenzo-blanco, E. I., Unger, J. B., Baezcondegarbanati, L., Ritt-olson, A., \& Soto, D. (2012). Acculturation, enculturation, and symptoms of depression in hispanic youth: The roles of gender, hispanic cultural values, and family functioning. Journal of Youth and Adolescence, 1350 65. doi:10.1007/s10964-012-9774-7.

Maulina, R. D., \& Amalia, S. (2019). Keberfungsian keluarga bagi penyesuain sosial mahasiswa baru. Jurnal Psikologi, 15(1), 57-67. doi:10.24014/jp.v14i2.6886.

Ningsih, D. S., \& Herawati, T. (2017). The influence of marital adjustment and family funtion on family strength in early marriage. Journal of Family Science, 2(2), 23-33. doi:10.29244/jfs.2.2.23-33.

Notoatmojo. (2003). IImu kesehatan masyarakat: Prinsip-prinsip dasar. Jakarta, ID: Penerbit Rineka Cipta.

October, K. R. (2018). An investigation into the correlates of family resilience in an impoverished rural community in the Western Cape (Tesis). Bellvile, FR: University of the Western Cape.

Oltmann, S. M. (2009). Information Access. Indiana University School of Library \& Information Science.

Pamungkas, R. A., Chramroonsawasdi, K., \& Vatanasomboon, P. (2018). Family functioning integrated with diabetes selfmanagement: A concept analysis. Frontiers of Nursing, 5(3), 199-206. doi:10.1515/fon-2018-0027.

Peter, P., \& Olson, J. C. (1999). Perilaku konsumen dan strategi pemasaran (Jilid 1 Edisi Keempat). Sihombing, D., Penerjemah; Sumiharty, Editor. Indonesia, ID: Erlangga.

Priasmoro, D. P., Widjajanto, E., \& Supriati, L. (2016). Analisis faktor-faktor keluarga yang berhubungan dengan perilaku agresif pada remaja di kota malang: Pendekatan teori struktural fungsional keluarga. Jurnal IImu Keperawatan, 4(2),114-126.

Puspitawati, H. (2012). Gender dan keluarga: Konsep dan realita di Indonesia. Bogor, ID: IPB press.

Raharjo, T. I., Puspitawati, H., \& Krisnatuti, D. (2015). Tekanan ekonomi, manajemen keuangan, dan kesejahteraan keluarga muda. Jurnal IImu Keluarga dan Konsumen, 8(1), 38-48, doi:10.24156/jikk.2015.8.1.38.

Richardson, R. C., \& Gleeson, J. P. (2018). Family functioning, parenting style, and child behavior in kin foster care. Families in Society: The Journal of Contemporary Social Services, 93(2), 111-122. doi:10.1606/1044-3894.4196.

Rochaniningsih, N. S. (2014). Dampak pergeseran peran dan fungsi keluarga pada perilaku menyimpang remaja. Jurnal Pembangunan Pendidikan: Fondasi dan Aplikasi, 2(1), 59-71. doi:10.21831 /jppfa.v2i1.2618.

Roman, N. V., Schenck, C. S., Ryan, J., Brey, F., Henderson, N., Lukelelo, N., MinnaarMcDonald, M., \& Saville, V. (2015). Relational aspects of family functioning 
and family satisfaction with a sample of families in the western cape. Social Work, 52(1), 302-312. doi:doi.org/10.15270/52-2511.

Siregar, S. M., Nadhiroh. (2016). Peran keluarga dalam menerapkan nilai budaya suku sasak dalam memelihara lingkungan. Jurnal Green Growth dan Manajemen Lingkungan, $\quad$ 5(2), 30-42. doi:10.21009/jgg.052.04.

Sunarti, E. (2015). Ketahanan keluarga Indonesia. Indonesia, ID: IPB Press.

Sunarti, E. (2013), Tipologi keluarga di wilayah perdesaan dan perkotaan. Jurnal IImu Keluarga dan Konsumen, 6(2), 73-81. doi:10.24156/jikk.2013.6.2.73.

Sunarti, E., Johan, I. R., Haryati, C. (2010). Hubungan fungsi AGIL dengan kesejahteraan keluarga nelayan yang rawan terkena bencana alam. Jurnal IImu Keluarga dan Konsumen, 3(1), 11-17. doi:10.24156/jikk.2010.3.1.11.

Syahmala, N. (2015). Perempuan orang tua tunggal dalam pelaksanaan fungsi keluarga di Kecamatan Dumai Selatan Kota Dumai. Jom FISIP, 2(2), 1-16.

Wijayanti, U. T., \& Berdame, D.Y. (2019). Implementasi delapan fungsi keluarga di Provinsi Jawa Tengah. Jurnal Komunikasi, 11(1), 15-29. doi:10.24912/jk.v11i1.2475.

Yang, S., \& Hong, J-A. (2015). Factors influencing family-function in families of pathological gamblers. Journal of Korean Academic Psychiatry Mental Health Nursing, 24(3), 196-206. doi:10.12934/ jkpmhn.2015.24.3.196.

Zabriskie, R. B., Aslan, N., \& Williamson, M. (2018). Turkish family life: A study of family leisure, family functioning, and family satisfaction. Journal of Leisure Research, 49(1), 8-27. doi:10.1080/00222216.2018 .1425049 .

Zamani, Z. A., Nasir, R., Desa, A., Khairudin, R., \& Yusooff, F. (2014). Family functioning, cognitive distortion and resilience among clients under treatment in drug rehabilitation centres in Malaysia. Procedia-Social Behavioral Science, 140, 150-154. doi:10.1016/j.sbspro.2014 .04 .401 . 